DOI: 10.4274/tpa.1005

\title{
Sağ uyluk bölgesinde şişlik olan yedi yaşında erkek çocuk
} A seven-year-old boy with a tumour on his right upper leg

Mehmet Hanifi Okur, Ibrahim Uygun, Hayati Güneş*, Ilyas Yolbaş* ${ }^{\star *}$ Selçuk Otçu

Dicle Üniversitesi Tip Fakültesi, Çocuk Cerrahisi Anabilim Dalı, Diyarbakır, Türkiye *Namık Kemal Üniversitesi Tıp Fakültesi, Tıbbi Mikrobiyoloji Anabilim Dalı, Tekirdağ, Türkiye

**Dicle Üniversitesi Tıp Fakültesi, Çocuk Hastalıkları Anabilim Dalı, Diyarbakır, Türkiye

\section{Olgu}

Kırsal bölgede yaşayan yedi yaşında bir erkek çocuk sağ uyluk bölgesinde 1,5 yıldan beri var olan ancak son üç aydır boyutları artan, ağrıya ve yürüme güçlüğüne neden olan şişlik yakınması ile başvurdu. Hastanın fizik muayenesinde sağ uyluk adduktör bölgesinde $4 \times 6 \mathrm{~cm}$ çapında yumuşak kıvamlı, eritemsiz kitle saptandı. Hastanın travma, cerrahi veya herhangi bir hastalık öyküsü yoktu.

Laboratuvar tetkiklerinde eozonofili (\%15,4), lökositoz (14 000 /mmc) ve CRP $37,7 \mathrm{mg} / \mathrm{dL}$ saptand.

Ultrasonografide (USG) sağ uyluk anterior-medialde kas içi yerleşimli kalın kapsüllü, yaygın internal septasyonlar içeren 27x44 mm boyutlarında kistik ölçütlerde lezyon alanı saptandı.

Bu aşamada gerekli kan tahlili ve manyetik görüntüleme yapıldı. 


\section{Tanı: Hidatik kist}

Echinococcus için yapılan Eliza testi pozitif idi.

Manyetik Rezonans (MR) çalışmasında sağ uyluk anteriormedial kesimde internal septasyonlar bulunan, düzgün sınırlı T1 ağırlıklı serilerde hipointens, T2 ağırlıklı serilerde hiperintens, iv kontrast madde enjeksiyonu sonrası belirgin bir kontrast tutulumu göstermeyen kistik yapıda, 28x44 mm boyutlarında lezyon (Kist hidatik?) saptandı. Lezyon periferinde kontrast tutulumu (enflamasyon) vardı (Resim 1).

Preoperatif $10 \mathrm{mg} / \mathrm{kg}$ albendazol 10 gün boyunca verildi. Hastadan bilgilendirimiş onam formu alındıktan sonra, genel anestezi altında yapılan operasyonda kistin adduktör ve sartorius kasları arasında lokalize olduğu görüldü. Kistik kitleye zarar verilmeden total olarak eksize edildi (Resim 2) ve loj hipertonik salinle yıkandı, daha sonra kitle açılınca içinde

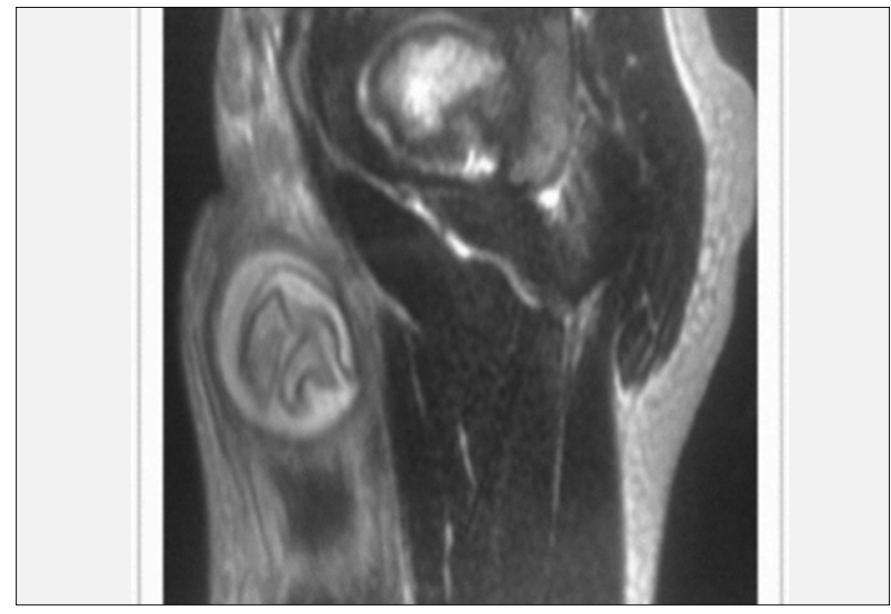

Resim 1. Sağ uyluk bölgesi MR görüntüleme

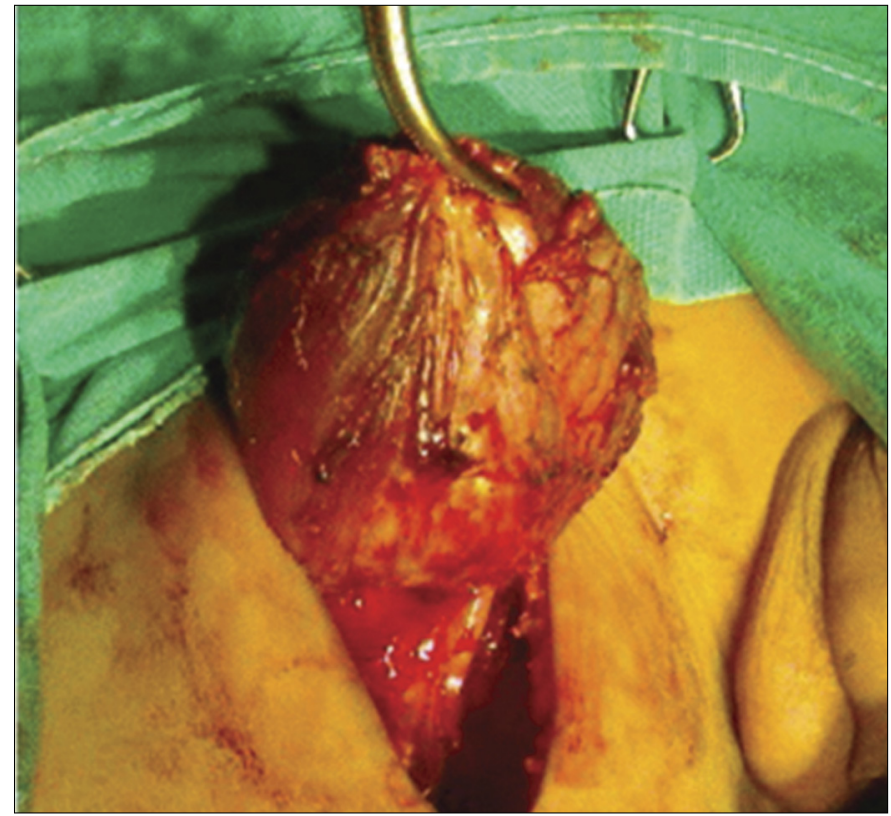

Resim 2. Kitlenin tümünün çıkarılışı germinatif membran ve kaya suyu olduğu görüldü (Resim 3). Post operatif sıkıntı yaşanmadı. Hastaya $10 \mathrm{mg} / \mathrm{kg} / \mathrm{gün}$ albendazol üç ay boyunca verildi.

\section{Tartışma}

Hidatozis eski zamanlardan beri bilinen parazitik bir hastalıktır. Bu hastalığa neden olan dört farklı parazit vardır. Bunlar Echinococcus granulosus, E. Multilokularis, E. Vogeli ve E.oligarthrus' tur. Bu parazitlerden klinik önemi olan ilk ikisidir. Diğer iki parazitin insanda enfeksiyona neden olması nadirdir (1). Hastalık Akdeniz ülkeleri, Ortadoğu, Avustralya, Güney Amerika gibi birçok ülkede endemiktir. Türkiye'de yılık insidansı 100 000'de 12'dir (2).

Hidatik kist çocuklarda akciğerlerde \%64, karaciğerde \%28 oranında bulunur, bunların yanında beyin, peritoneal kavite, dalak, kalp ve kemik yerleşimi de vardır (3). Çocukluk çağında kas dokusunda oluşan birincil enfeksiyonun E. Granulosus ile oluştuğuna inanılır. Çocuklarda nadir, erişkin yaşta sık görülmesi kistin yavaş büyümesi ve bulguların ilerleyen yıllarda ortaya çıkmasına bağlıdır (4).

Birincil iskelet kası hidatik kisti nadirdir ve \%0,5-\%4,7 oranında görülür. Kist büyümek için oksijeni kullanır. Buna karşın kaslarda laktik asit bulunur, dolayısıyla bu ortam kistin büyümesi için elverişli değildir (4). Hidatik kistin iskelet kası lokalizasyonuyla ilgili patojenezi tam olarak ortaya konulamamıştır. Bazı yazarlara göre enfekte köpek ısırığı ile, bazı yazarlara göre de embriyonun akciğer ve karaciğer gibi filtre görevi gören iki organı geçtikten sonra iskelet kasına ulaşması sonucu oluştuğu öne sürmektedirler (7).

Literatürde bildirilen birincil iskelet kası hidatik kisti olguları yaklaşık 60 adettir ve hastalar çoğunlukla erişkindirler (5). Çocuklarda çok nadirdir (69).

Birincil intermusküler yerleşimli hidatik kist tanısını koymak endemik bölgeler haricinde zordur. Ayırıcı tanıda apse, hematom, yumuşak doku tümörü ve diğer lezyonlar düşünülmelidir. Biyopsi canlı skolekslerin dolaşıma girerek, yayılıp anaflaktik bir reaksiyona neden olması ve diğer kompartımanları enfekte etmeleri açısından sakıncalı

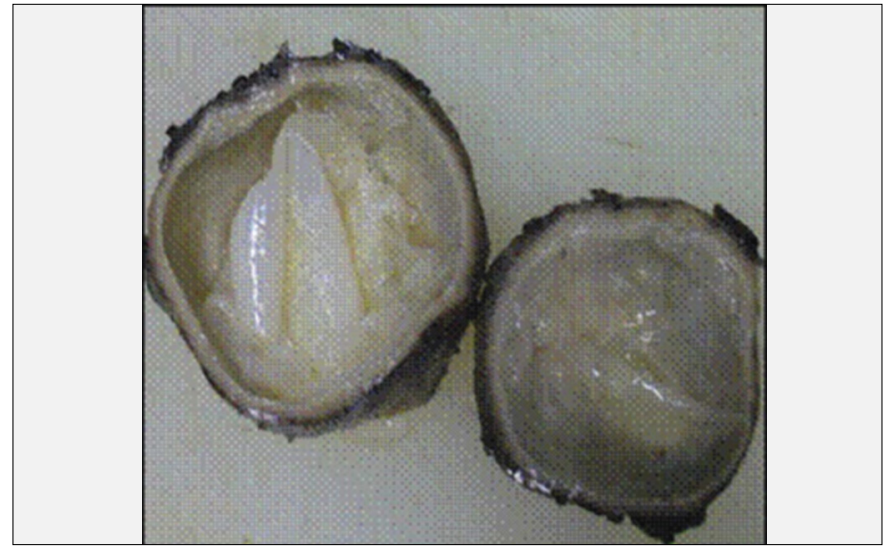

Resim 3. Kitle içinde jerminatif membran 
olacağından biyopsi yapılmaması gerekir ve bu nedenle de şişliklerde öncelikle görüntüleme çok önemlidir (8).

Olgumuz çocukluk çağında birincil intermusküler yerleşimi ve $5 \mathrm{~cm}$ boyutu nedeniyle çocukluk çağında literatürde görülen ikinci olgudur.

Musküler hidatik kist nadir görülmesine karşın endemik olarak görüldüğü kırsal yerlerde halen önemini korumaktadır. Olağandışı yerleşimli musküler hidatik kist tanısında radyolojik görüntüleme teknikleri ve serolojik testlerden faydalanılabilir. Ultrasonografi sonucu bazen apse ile karışıp yanıltıcı olabilir, MR'da hidatik kistin belirgin hipointens kenar yapısı görülebilir (9).

Serolojik testler tanıyı doğrulamak için kullanılabilir. İndirekt immünofloresan antikor testi, ELISA, immünoelektroforez ve immünoblast testleri yaygın olarak kullanılan tekniklerdir (10). Hastamızın tanısı radyolojik, serolojik ve histopatolojik olarak ortaya konulmuștur.

Sonuç olarak hidatik kistin endemik olarak görüldüğü yerlerde kistik kitle ile başvuran hastalar da hidatik kist göz ardı edilmemeli ve şüpheci davranılıp biyopsi yapılmadan önce hidatik kiste yönelik radyolojik ve serolojik tetkikler yapılmalıdır. Eğer sonuçta hidatik kist düşünülüyor ise kitle total olarak çıkarılmalı, drenaj yapılmamalıdır.

\section{Kaynaklar}

1. Merkle EM, Schulte M, Vogel J, et al. Musculoskeletal involvement in cystic Echinococcosis: report of eight cases and review of the literature. AJR Am Roentgenol 1997;168:1531-4.

2. Republic of Turkey Ministry of Health. Health statistics. Ankara: Research planning and Coordination Council;1997.

3. Tsakayiannis E, Papis C, Moussatos G. Late result of the conservative surgical procedures in hydatid disease of the lung in children. Surgery 1970;68:379-82.

4. García-Díez Al, Ros Mendoza LH, Villacampa VM, Cózar M, Fuertes MI. MRI evaluation of soft tissue hydatid disease. Eur Radiol 2000;10:462-6.

5. Mseddi M, Mtaoumi M, Dahmene J, et al. Hydatid cyst in muscles: eleven cases, Rev Chir Orthop Reparatrice Apar Mot 2005;91:267-71.

6. Cankorkmaz L, Ozturk H, Koyluoglu G, Atalar MH, Arslan MS. Intermusculer hydatid cyst in a 4-year-old child: a case report. J Pediatr Surg 2007;42:1946-8.

7. Melis M, Marongiu L, Scintu F, et al. Primary hydatid cyst of psoas muscle. ANZ J Surg 2002;72:443-5.

8. Duncan GJ, Tooke SM. Echinococcus infestation of the biceps brachii. A case report. Clin Orthop Relat Res 1990;261:247-50.

9. Pedrosa I, Saiz A, Arrazola J, Ferreirons J, Pedrosa CS. Hydatid disease: radiologic and pathologic features and complications. Radiographics 2000;20:795-817.

10. Zhang W, Li J, McManus DP. Consept in immunology and diagnosis of hydatid disease. Clin Microbial Rev 2003;16:18-36. 